\title{
The effects of grazing by goats and sheep, separately or in combination, on hill vegetation
}

\author{
S. Scanlan ${ }^{1}$ and G. E. J. Fisher ${ }^{2}$ \\ 'Scottish Agricultural College, Grassland and Ruminant Science Department, Kirkton Farm, Crianlarich \\ 'Scottish Agricultural College, Grassland and Ruminant Science Department, Auchincruive, Ayr KA6 5HW
}

\section{Introduction}

There is potential for the rôle of cashmere production from goats in the diversification of hill farming enterprises. For systems to succeed, emphasis needs to be placed on grazing indigenous hill pastures as well as sown in-bye swards. This is particularly the case in cool, wet western regions where landscape and wildlife conservation values are high. The objectives of this work were to investigate the effects of goat and sheep grazing on indigenous pastures to enable prediction of the consequences of this diversification on sites of wildlife conservation value.

\section{Material and methods}

The experiment was established and started in August 1991 on hill pasture at Auchtertyre Farm, Crianlarich, west Perthshire. The work will continue, initially, until December 1993. Three grazing treatments are used each having a 2.9-ha fenced paddock, viz: S - sheep only; GS - goats and sheep; G- goats only.

In 1991 grazing commenced 20 August and continued until 19 December and the S, GS and G paddocks were set-stocked at $99.3,92.8$ and $87.5 \mathrm{~kg}$ live weight per ha, respectively. In 1992 grazing commenced 22 May and will continue to mid December. The paddocks were again set-stocked with $72.4,72.2$ and $72.4 \mathrm{~kg}$ live weight per ha, respectively.

Eight plant communities were identified in each paddock, characterized by: (1) herb-rich Fescue/ Agrostis; (2) Nardus stricta; (3) Juncus spp; (4) Trichophorum caespitosum; (5) Calluna vulgaris; (6) Myrica gale; (7) Eriophorum augustifolium and (8) Molinia caerulea. The height of each of these main species was recorded in each paddock every 10 days using a Hill Farming Research Organisation swardstick. Twenty measurements were taken for each species on each occasion and the same areas were used for these measurements over the grazing season. In addition, 290 random herbage heights were recorded in each paddock at the start, middle and end of each grazing season. At the start of the experiment, four permanent $1-\mathrm{m}^{2}$ quadrats were set up in each community of each paddock. Each quadrat was subdivided into 25 squares and all species were recorded in each square along with a ground cover score of the main species. Changes in the diversity and abundance of flora will be recorded by returning to these quadrats at the end of the experiment.

All animals were weighed at the start and end of each grazing season. The paddocks were closed-up over winter and left ungrazed.

\section{Results and discussion}

The initial results suggest that goats in treatments G and GS preferentially graze Juncus spp., Myrica gale and Molinia caerulea in comparison with sheep in treatment $S$. This was shown by the specific herbage height measurements, presented in Figure 1. To date in 1992, goats in the GS paddock have not grazed Juncus spp. and Myrica gale to as low a height as goats in the $\mathrm{G}$ paddock.

There were no differences among treatments for random herbage heights, either analysed as a whole or according to different altitudes within each paddock. Random herbage heights $(\mathrm{cm})$ on 15 August 1991 in the G, GS and S paddocks were 9.7, 9.6 and 8.7 (s.e.d. 3.54) respectively. The corresponding heights on 4 May 1992 were 6.4, 6.3 and 6.0 (s.e.d. $0 \cdot 63$ ).

The effects of grazing treatment on the diversity and abundance of flora will only become apparent when the permanent quadrats are revisited at the end of the experiment. Grazing by goats may reduce the proliferation of Molinia caerulea, but may also eliminate certain species such as Myrica gale. 
In the 1991 season, grazing in the GS treatment was competitive between goats and sheep with goats losing more and sheep gaining less weight than their counterparts in the $\mathrm{G}$ and $\mathrm{S}$ treatments.

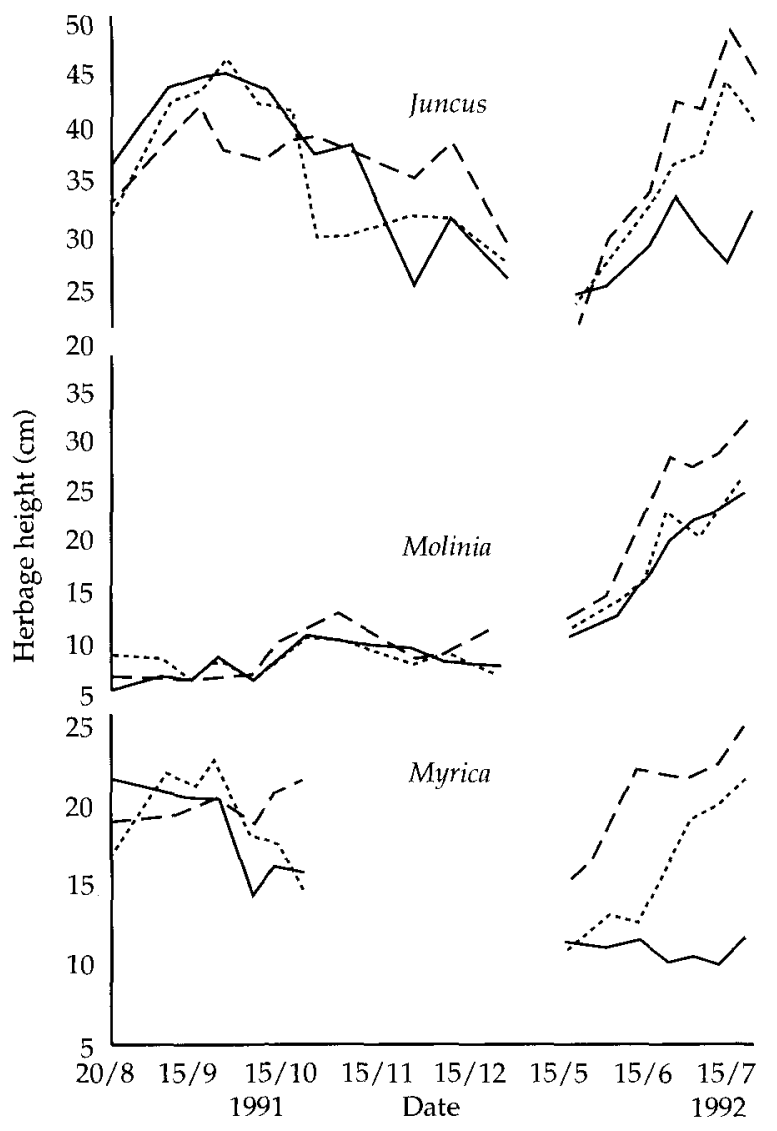

Figure 1 Herbage heights of (a) Juncus acutiflorus, (b) Molinia caerulea and (c) Myrica gale in the G (-), GS (...) and $\left.S(-)^{-}\right)$paddocks. 